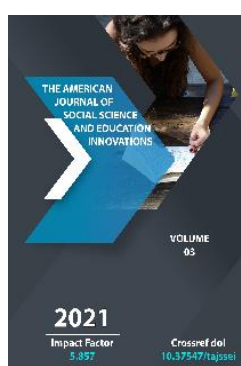

Copyright: Original content from this work may be used under the terms of the creative commons attributes 4.0 licence.

\section{The Role Of Discourse As A Phenomenon Of Language In Studying Internet-Mediated Communication}

Igor Felixovich Porubay

Lecturer, Ferghana State University, Uzbekistan

Erkin Tuychiyevich Khakimov

Candidate Of Philosophical Sciences, Associate Professor, Ferghana State University, Uzbekistan

\title{
ABSTRACT
}

This article is dedicated to the role of discourse and discourse analysis in the process of the linguistic study of Internet-mediated communication. The article analyses the meaning of the concept of "discourse" in linguistics and modern approaches to this phenomenon. The main properties of the Internet discourse and the boundaries of its discursive space are described.

\section{KEYWORDS}

Discourse, Discourse analysis, Discourse space, Internet, Internet discourse, Computer discourse, Computer-mediated communication.

\section{INTRODUCTION}

The role and significance of discourse analysis in the study of the language of communication mediated by information technologies occupies one of the leading places in modern linguistics. The reason for this is the social aspect of the industry of discourse analysis, in which a variety of extra-linguistic factors, such as social, age, professional, etc., play an important role. All these circumstances are taken into account in the process of a discursive approach to language. In the environment of information technologies and the language of Internet communication, these factors are quite obvious and are manifested 
especially clearly in view of the important place of computer technologies in the life of modern society and the individual.

At the moment, it is almost impossible to imagine a socially rich life with all its forms and manifestations outside the influence and presence of computer technologies - the dependence of society on the modern communicative functions of IT and the Internet is so great. Most of our communication is related to the use of remote means of communication, including the exchange of messages via the Internet, mobile networks, and e-mail correspondence. Even our communication in the leisure area is provided in the format of social networks, forums and messengers on the Web, and the tendency for a greater increase in the number of participants in communication on the Internet is becoming more noticeable every year.

In this communicative environment, the language itself as a means of communication undergoes many changes at various levels, since the Internet itself and information technologies contribute to the development of a new meaning of words, the emergence of neologisms, the popularization of new terminology and the entry of terms into everyday use. A variety of morphological, stylistic processes can be traced, new words are created with a certain stylistic coloring, for example, jargon and slang; there is a process of borrowing words from one language to another with subsequent changes, etc. All these processes and properties are most visible within the framework of the analysis of the Internet language as a discourse, where completely diverse properties are taken into account, taking into account factors outside the language as an object of research, for example, the discourse environment, social, cultural and psychological factors are important.

In this case, the question arises about the nature and definition of discourse as a separate phenomenon of language, the correct understanding of which is fundamental in concretizing the approaches of discourse analysis of the language of Internet communication. The problem of defining the concept of discourse is due to the fact that at different times of its formation as a scientific concept, discourse acquired various interpretations that complemented each other, but could be explained in different ways in view of the specific objectives of the study.

One of the reasons for the lack of a clear definition of discourse is the etymology of the term itself, which is interdisciplinary and, in view of this fact, can be perceived differently by the researcher. The very word "discourse" dates back to antiquity. In the days of ancient Rome, the word "discourse" meant a conversation or speech of scientists. In the Brothers Grimm German dictionary, discourse is explained as "dialogue" or "conversation", and also has definitions such as "speech" or "lecture."

\section{MATERIALS AND METHODS}

The preconditions for the concept of discourse precisely as a phenomenon of language in linguistic science can be attributed to the period of the Second World War, namely to the article of 1943 by the Belgian scientist and representative of the Geneva scientific school E. Buissens [1]. In his work, the author for the first time suggested the presence in the language of a certain "border zone" between the language as a system of signs and speech as a product of the use of this system. The existence of this "mediating" zone was the 
prerequisite for the concept of "discourse" - a means of bringing "live" speech to life through the use of language.

Most of the early studies of discourse as a scientific phenomenon and the introduction of the term itself as such in modern science, however, was carried out by the American scientist Zelig Harris in the early 50 s of the XX century, who in modern science is recognized as the founder of approaches to the definition and study of this concept. Harris proposed to introduce the concept of "discourse" as an extension of the scale of units of language, and considered discourse as a separate unit of language, in terms of volume following a sentence. According to these views, discourse is equated with the concept of a text. Harris's works were socially oriented, which provided the prerequisites for considering discourse as a phenomenon inextricably linked with the existence and life of society.

In the dictionary of literary terms, one can find the following definition: "discourse is such a dimension of a text taken as a chain / complex of statements (ie, as a process and result of a speech (communicative) act), which assumes within itself syntagmatic and paradigmatic relations between the constituents of the system formal elements and reveals the pragmatic ideological attitudes of the subject of the statement, limiting the potential inexhaustibility of the meanings of the text " [2]. This definition pays attention to the nature of discourse as an equivalent of the text, which manifests itself through direct expression by the participant in the conversation, where his individual views, attitudes, opinions, etc., matter.Nevertheless, understanding discourse only as a text could not remain satisfactory for a long time, and in the mind of a modern researcher, discourse is a broader concept than text or speech, which finds its evidence in its manifestations in life.

The first of the researchers to draw attention to the broader nature of discourse, going beyond the concept of "text", was the American scientist T. Van Dijk. In the works of Van Dyck, attention is drawn to the fact that discourse manifests itself as a means of communication, i.e. discourse exists within a certain "social situation" [3]. Thus, the social situation can influence the properties of discourse - style, emotional coloring of speech acts, the course of communication, the specific composition of words, phrases, etc. In this case, discourse appears as a socially outlined phenomenon, where the influence of social factors is quite obvious.In English-language literature, discourse is understood as speech, conversation, serious conversation, language used in certain specific areas in oral or written forms.

\section{RESULT AND DISCUSSION}

The modern presentation of discourse includes both linguistic and non-linguistic factors, such as knowledge, attitudes, opinions, etc [5]. Modern linguistics puts discourse as a term that is similar or related in meaning in relation to concepts such as "speech", "speech act", "rhetoric", "text", "dialogue", "conversation", "interaction", "context " [6].

For this reason, in modern science, several interpretations of discourse can be distinguished, namely, formal, functional and situational [7]. The first, formal interpretation is the earliest of all and considers discourse as a text, which is consistent with the views of Harris. The second, functional interpretation focuses on discourse as the phenomenon of using language as a system in the process of communication, creating a semantic message. 
The third, situational interpretation, analyzes discourse in terms of the influence on it of various extralinguistic factors dictated by social circumstances, within which it manifests itself.

Modern studies of discourse analysis, according to L.P. Prokoshenkova, are aimed at "identifying the social context behind oral or written speech, studying the relationship between language and social processes" [8]. According to D. Lepsheeva, discourse is "an oral or written form of a text (speech work) addressed to the addressee, conjugated a semantically related speech situation, which is an integral communicative (speech) unit and functions in the form of a monologue - dialogue ". The speech situation in this interpretation provides for the social circumstances in which the discourse exists.

At present, in the eyes of most researchers, the most satisfactory are the functional and situational interpretations of discourse, since they include all aspects of the existence of discourse, including its functioning in society, the influence of extralinguistic, external factors on the properties of discourse as a linguistic phenomenon, such as discursive environment, social factors of the participants in the discourse, including professional affiliation, age, relationships between interlocutors, psycholinguistic factors, etc.

The study of discourse at the present stage is carried out in several fundamental directions, each of which focuses on a specific element of discourse. They include:

1. Study of the cognitive properties of discourse (T. van Dijk, P. Hopper)

2. Studying the properties of discourse with an emphasis on the cognitive characteristics of participants in the discourse (D. Gordon)

3. Studying the structure of discourse through the cognitive characteristics of its participants (D. Jefferson, D. Shifrin) [10].

Regarding the discourse of Internet communication, it is necessary to understand the boundaries of its "space", which is key in understanding its impact both inside and outside this space. The space of a specific type of discourse is the sphere of its use, the determining factors of which can be various moments, mainly socially dictated. Discourse can also be categorized according to other criteria, such as age. Everyone knows that the manner of communication of one individual as a participant in a conversation can vary dramatically depending on the age difference between him and the interlocutor. The same is true for the properties of discourse, the features of which are determined by the interpersonal relationships between the participants in the conversation. A polylogue or dialogue between parents and children has significantly different linguistic characteristics compared to communication between peers, brothers and sisters; including the difference in the style of language, speech patterns, various formalities in the process of communication, features of a purely cultural plan, etc. Discourse analysis as the study of discourse, which is initially a phenomenon at the intersection of many scientific disciplines, includes the application of methods and approaches of psycholinguistics, pragmatics, cultural linguistics and other branches of knowledge. In the case of Internet discourse, we are primarily interested in the scope of its application both professionally and purely socially, since the phenomenon of the Internet itself has long been firmly entrenched in 
people's daily life and has a visible impact on its course and trends. Here, the issue of the space of the Internet discourse acquires great importance, which can help in establishing a specific zone of influence of the Internet sphere on communication and especially in the process of analyzing such communication.

S.N. Plotnikova writes that "discursive space is understood as" a kind of logical environment in which discourses and discursive personalities coexist - people who produce these discourses." [11]. Thus, the discourse itself exists in a certain space in which the participants of this discourse are directly located. There is an obvious logic in this interpretation if we take into account the professional factors of the discourse space. For example, there is the discursive space of programmers - a set of the most commonly used words, expressions, and phrases that are used in the environment of programmers in everyday communication with each other. This understanding of discourse includes terms, jargons, slang that are used by participants in the discourse, etc. What are the boundaries and properties of the discourse space of the language of Internet communication? It should be noted that the language of Internet communication, or, as it is commonly called in modern linguistics "Internet discourse", is part of the broader concept of "the language of communication mediated by computers." The term was originally introduced in Englishspeaking science, namely Computer-Mediated Communication (CMC) - "Any communication in which users interact via the direct use of a computer" [12] - "Any form of communication in which users interact with each other through the use of computers".

Communication mediated by computers is possible only when computers and computer technologies are used as tools that provide communication through their technical capabilities (computers, smartphones, software, the Internet, mobile networks) due to certain restrictions under which communication is directly or impossible (topologically long distance of participants communication in real space), or is voluntarily chosen by the participants of communication as a preferable form of communication, which is especially manifested among young people who are inclined to communicate "online" to a much greater extent. Communication in such a technologically conditioned way, however, requires certain skills from the communication participant, the same as the knowledge of any language in communication in general. The first criterion is access to information technology from all sides of communication, i.e. each communication participant must have access to Internet communication to the extent that communication allows them. It should be noted that communication sometimes may not be entirely equal, and depends on the technical capabilities of the hardware at your disposal (computers, as a rule, often have more capabilities than smartphones), the functionality of the operating network and programs of the hardware part, as well as the quality networks that provide communication (of course, a communication participant who is in a mobile network may experience a communication delay or even "drop out" from it when the connection is broken).

The second criterion is the skills of individuals' possession of means of communication, in other words, computer literacy. In the absence of the individual's possession of these skills, the basic ones of which are sufficient for the implementation of the text format of Internet communication, communication is not 
possible. At the present stage, there is still a certain percentage of people who do not have computer literacy, sometimes for reasons beyond their control, for example, due to the impossibility of access to such technologies, or any physical limitations, for which work is underway to facilitate access to such technologies.

Internet communication, due to technical innovation and constant development, as well as the obvious popularity, ergonomics and accessibility, in modern times, for the most part, affects the language and manner of communication within its discursive space, which, in turn, is limited by the functionality of the information technology sphere. Thus, the language of the Internet, being part of the language of communication mediated by computer technologies, has its own discursive space. This space, however, has interesting characteristics, since it manifests itself not only within itself, but also affects the language outside it, and is the basis for the formation of new words, meanings and terminology.

For a full explanation of these processes, let us take the sphere of computer technology as such. If we look at it in the context of relationships with language, we can distinguish, according to the views of E.N. Galichkina, three "dimensions": 1) thematic - a conversation about computers and everything connected with them. 2) personological conversations between participants in the discourse that are professionally related to the field of computer technology, and these conversations, of course, relate to the same area of computers. 3) instrumental - just the dimension in which computer technologies realize the very possibility of communication, both on the topic of computers and any other [13]. The instrumental dimension of the computer sphere is the foundation for the existence of the Internet discourse. Nevertheless, the thematic dimension can be traced within the instrumental dimension (where participants in communication often talk about the specifics of computers, the Internet, describe and respond to the functionality of software); as well as words within the personal dimension, for example, terms related to the operation of programs or Internet services, such as torrent trackers, forums, chats.

Thus, the sphere of Internet discourse and computer discourse as a whole influences the language from many sides and influences the appearance of the modern language and its tendencies both inside and outside its space. For example, an increasing number of people who do not use communication mediated by the Internet on an ongoing basis still have an idea of the most frequently used words in the Internet discourse, for example, "hang up", "throw off", "post”, etc.

Internet discourse is considered by some researchers not only from the point of view of simple communication in general through the Internet and its capabilities. E.G. Gribovod, for example, distinguishes various subcategories in Internet communications, each of which is considered as a separate type of discourse, for example, e-mail discourse, discourse of asynchronous (forums) and synchronous communication (messengers), etc [14].

Nevertheless, all of the above situationally dictated types of discourse exist in the paradigm of the discourse of Internetmediated communication, for this reason, such a detailing of categories depends on the objectives of the study. If we take into account 
the genres of communication, then this approach is quite justified.

You should also pay special attention to another, distinctive feature of the discursive space of the language of Internet communication. When it comes to understanding space as a component of discourse in general terms, there are several criteria for its framework. The first criterion is purely physical space and the presence in it of the participants of the discourse, interlocutors in relation to each other. The second criterion is the time frame in which the discourse takes place. Other factors of the discursive space can be the nature of the conversation, the topic, the interpersonal relationships of the interlocutors, the frequency of their verbal interaction, the level of familiarity with each other, etc. All these criteria define the boundaries and properties of discourse, forming their type.

\section{CONCLUSION}

It should be emphasized here that the basic criteria of space have purely physical characteristics - say, the location of interlocutors in the physical plane, the frequency of contacts of interlocutors (for example, the physically conditioned close proximity of neighbors or work colleagues in relation to each other determines a potentially higher level of communication frequency between them). In general, all the criteria of the discursive space are in the zone of the physical, real world. However, in the case of the discourse of Internet communication, the physical space is only part of its overall picture. The discourse of the Internet, due to its nature, creates a virtual environment through which many everyday types of human activity are carried out, such as working with information, accessing it, creating it and directly communicating. The very term "virtuality" is something that has all the characteristics of a particular thing, but formally cannot be defined as this thing [15]. Indeed, our interaction with information technology takes place in a virtual environment created by software. The results of this activity have value and influence, as well as characteristics of the physical, real world, however, not having a physical form. For example, communication via the Internet, as everyone knows, is carried out through such a virtual environment through programs and network services, at the same time being real communication, however, without the obligatory presence of interlocutors in one physical space (of course, the participants in the discourse can be located in completely different parts of the world) and even outside of one time frame - messages are saved and can be read by the interlocutor later. Thus, the discursive space of Internet communication is "hybrid", where the communication process takes place in a virtual environment, and the interlocutors are directly in real space.

\section{REFERENCES}

1. Buyssens E. De l'abstrait et du concret dans les faits linguistiques: la parole, le discours, la langue // Acta Linguistica. 1943.№ 3. P. 17-23.

2. Словарь литературоведческих терминов. Электронный ресурс.URL : http://dic.academic.ru

3. Дейк Т.Ван «Язык. Познание. Коммуникация». . пер. с англ. М.: Прогресс, 1989 - с.345

4. Webster's CollegiateThesaurus: Springfield, 1976. 
5. Макаров М.Л. Основы теории дискурса. - М., 2003. - с.20-26

6. А. Н. Бокаева, Х. Х. Нурсеитова. «К определению понятия "дискурс»».Linguamobilis № 1 (34), ООО «Энциклопедия». 2012 - с.20

7. Макаров М.Л. Основы теории дискурса. - М., 2003-с.86

8. Л.П.Прокошнекова, И.Б.Гецкина. «Дискурсивный анализ и его роль в современной лингвистике». Вестник ЧГУ. ФГБОУ ВО «ЧГУ Им. И.Н. Ульянова» 2006 г. - с.

9. Лепшеева Н.А. «Жанровые особенности компьютерного дискурса» Вестник ЧелГУ. №43 Филология вып.39 (181) 2009 - 89 с.

10. Поскачина Е.Н., Жирков М.И. «Определение дискурса в современной лингвистике». В мире науки и искусства: вопросы филологии, искусствоведения и культурологии. №12 АНС «СибАК», 2016 г. - С.123

11. С.Н.Плотникова. «Дискурсивное пространство: к проблеме определения понятия». Magister Dixit. МГЛУЕАЛИ. 2011 г. - С.154

12. D.Chandler and R.Munday A Dictionary of Media and Communication (1 ed.)https://www.oxfordreference.com/ http://bit.ly/3bf56EX(дата обращения 7.01.2021

13. Е.Н.Галичкина. «Компьютерный дискурс». - «Дискурс Пи» - ИФиП УрО РАН, 2015 г. - 183 С.

14. Е.Г.Грибовод. «Интернет-дискурс». Дискурс Пи. ИФиП УрО РАН. 2013 г. c.119.

15. Cobuild Collins. Essential English Dictionary: Oxford Advanced Learner's
Dictionary of Current English. Harper Collins Publishers, 1995. - c. 797

16. Khakimov Erkin. Education and Business Collaboration in Conditions of Transitional Economics: Philosophy of Changes. Canadian Social Science, Vol. 16, No. 3, 2020, pp. 46-49

17. Khakimov Erkin Tuychiyevich. SUBJECT OF INNOVATION ACTIVITY-DEFINING ELEMENT OF MODERNIZATION OF THE SOCIETY.EPRA International Journal of Research \& Development (IJRD) Vol. 5, Issue 7 July, 2020.

18. Bakhromovich, S. I. DEVELOPMENT TRENDS AND TRANSFORMATION PROCESSES IN ACADEMIC MOBILITY IN HIGHER EDUCATION IN UZBEKISTAN AND THE WORLD.

19. Mirzarahimov, B. H. (2020). The Tasks Of Tourism In Aesthetic Education: The Harmony Of Historicity And Modernity. The American Journal of Social Science and Education Innovations, 2(09), 652658.

20. Erkin, K. (2020). Education and Business Collaboration in Conditions of Transitional Economics: Philosophy of Changes. Canadian Social Science, 16(3), 46-49.

21. Erkin, K. (2020). Dynamics Of Moral Relations In Uzbekistan: Social And Philosophical Aspect. The American Journal of Social Science and Education Innovations, 2(12), 375-381. 